DOI: https://doi.org/10.51209/platform.2.4.2021.205-228

УДК 821(47+67)-312.9.09:17.023.36

\title{
СПРОБИ ОСМИСЛЕННЯ КУЛЬТУРНО-ІСТОРИЧНИХ ПАРАДИГМ У ТВОРЧОСТІ БРАТІВ СТРУГАЦЬКИХ («СПРОБА ВТЕЧІ», «ВАЖКО БУТИ БОГОМ», «ПІКНІК НА УЗБІЧЧІ», «ЗА МІЛЬЯРД РОКІВ ДО КІНЦЯ СВІТУ»)
}

\author{
Іван Вікторович БРАТУСЬ, \\ кандидат філологічних наук, доцент, \\ Київський університет імені Бориса Грінченка, \\ Київ, Україна, \\ e-mail: i.bratus@kmaecm.edu.ua, \\ ORCID: 0000-0002-8747-2611
}

Анотація. У статті ми намагаємося продемонструвати осмислення зміни культурно-історичних парадигм у творчості братів Стругацьких. Здійснено аналіз основних творів письменників: «Спроба втечі», «Важко бути богом», «Пікнік на узбіччі», «За мільярд років до кінця світу» 3 точки зору переосмислення парадигм мислення. Доводиться, що кожна нова доба спричиняє нові фактори сприйняття дійсності. У статті робиться акцент на здатність братів Стругацьких передбачати майбутні зміни в суспільстві. Окрім цього, належне місце в дослідженні відводиться механізмам мотиваційного пошуку, що розкривалися в моделях ймовірного розвитку людства. Аналізуються елементи радянської дійсності, що додатково додають паралелізму творам письменників. Розглянуто фактори закріплення різноманітних елементів мислення в чітку структуру суспільного життя. Особливу увагу ми приділяємо «правді життя», що могла бути продемонстрована братами Стругацькими лише частково (цензурні обмеження). Нами введено в текст статті уривки 3 автобіографічних творів Сергія Довлатова - за допомогою цих цитат створюється більш повна картина радянської дійсності. Ця реальність дозволяє будувати умовні конструкти 
майбутнього, аналізувати сьогодення та здійснювати історичну ретроспекцію минулого. Фокус дослідження дозволяє нам відстежити відтінки зародження свободи у пізньому «застої», що було викликано поглибленням системної криси СРСР. Брати Стругацькі плідно працювали в царині з'ясування «внутрішньої мотивації радянської людини». Ці розвідки знаходили живий відгук у радянському суспільстві - їх творчість носила напівдемократичний формат, що за умов авторитаризму дуже цінувалося. Саме завдяки такому «статусу» письменникам вдалося залишити твори прийнятними для офіційного друку в СРСР та продемонструвати в них проблеми суспільства. В своїй творчій еволюції брати Стругацькі відійшли від вульгарного соціологізаторства перших своїх творів і здійснили справжній психологічних прорив в осмисленні людського буття, що почасти не втрачає актуальності і в описуваному ними XXI ст. При цьому дійсність у Стругацьких часто балансує на межі абсурду, що дозволяло їм більш глибоко відстежити механізми «долі».

Ключові слова: Борис Стругацький, Аркадій Стругацький, фантастика, парадигма мислення, радянська література, майбутнє

Вступ. У мистецтві XX ст. ми часто можемо спостерігати відчуття «загубленості». Автори замислилися про складність і непередбачуваність культурно-історичної парадигми розвитку суспільства, про закони «формування дійсності». Але сукупно зростаюча маса знань людей про дійсність не принесла визначеності та спокою - паралельно зростала недовіра до «справжності» цих знань, виникали сумніви у здатності осмислити існування. Письменники тонко передавали інтелектуальний пошук суспільства, поділяли біль недосконалості життя та намагалися віднайти якісь орієнтири в мороці буття.

Постановка проблеми. Саме XX ст. було надзвичайне багате на негативний досвід, що трансформувався у специфічний літературний доробок. Відповідно до позиції 
авторів змінювалися культурно-історичні парадигми письменники осмислювали різні шари розвитку минулого, сучасності та прогнозували майбуття. Творчість братів Стругацьких становлять собою концентрований літературний всесвіт, що ввібрав у себе думки, очікування та проблеми людей другої половини XX ст.

Мета статті - розглянути актуальну проблему зміни культурно-історичних парадигм на матеріалі деяких повістей братів Стругацьких.

Аналіз останніх досліджень і публікацій. Дослідники неодноразово зверталися до творчості братів Стругацьких. Проблеми, що поставили письменники-фантасти, й досі залишаються актуальними. Деякі аспекти їхнього доробку отримують «нове життя» в сучасних реаліях. Частина дослідників зосереджується на комплексі теоретичних літературознавчих проблем. Наприклад, Поліна Володимирівна Королькова розмежовує літературну казку та фентезі. Ї̈ дослідження [7] вносять ясність у складні питання жанрової класифікації подібної літератури: «Наприкінці 1960-х - на початку 1970-х рр. романтичне ставлення до науки в суспільстві стало змінюватися на насторожено-песимістичне, бо результати науково-технічної революції принесли не тільки блага, але i проблеми (екологічні, соціальні, морально-етичні). Все це не могло не позначитися на формуванні світогляду братів Стругацьких, їхньому ставленні до науки, яке виразилося в їх творчості і відбилося на художній концептосфері письменників» [9, сс. 92-93].

Деякі дослідники (Д. Антонець) звертають увагу на соціальні та політичні аспекти творчості братів Стругацьких: «Аспект протистояння людини й суспільства в даному творі $€$ ключовим для повісті Стругацьких і не тільки формує іiі хронотоп, але й виконує змістотворну функцію. Головний персонаж повісті представляється індивідуалістом у ситуації тоталітаризму. В останній сцені він розуміє, що він - маленька частина людства, і його поламане життя всім байдуже, бажання, загадане для самого себе, нічого не змінить ... » [1, с. 244]. 
Нами також був здійснений аналіз різних аспектів творчості письменників. Зокрема ми дослідили протидію системи та антисистеми в їх творчості [2] та фактори відображення свободи та несвободи [3].

Цікавими є спроби дослідників осмислити творчість Стругацьких дослідниками в порівнянні 3 іншими письменниками [4] та розгляд їх «соціальної метафізики» [8].

Мета статті - проаналізувати чотири твори братів Стругацьких у широкому культурно-історичному контексті.

Виклад основного матеріалу. Творчість братів Стругацьких мала надзвичайну популярність у СРСР. Ця популярність почасти збереглися й сьогодні. Ми могли спостерігати, як із плином часу значна частка їх літературного доробку дивовижним чином перейшла від розважальної пригодницької літератури до рівня майже пророчих творів. Безумовно, що всесвітньовідомі твори Свгена Замятіна, Джорджа Орвелла (George Orwell) та Олдса Хакслі (Aldous Huxley) мають значно більший розголос у світовій спільноті, надзвичайно широко популяризуються та досліджуються в порівнянні 3 роботами братів Стругацьких. Та ми можемо спостерігати, що пригодницька складова і почасти виконання ідеологічного замовлення не закаламутили чіткі контури культурно-історичних парадигм творів Стругацьких. Створенні в II пол. XX ст., ці твори відтворювали очікування від майбутнього та узагальнювали наявний історичний досвід. Уважне прочитання дозволяє виокремити історико-культурні парадигми, що поступово змінюються з розвитком суспільства. Зазвичай нам може заважати наявна в творах комуністична романтика, але вона здебільшого мала свого адресата в особі «юного читача», що сприймав подібні ходульні кліше часткою масивної державної пропаганди. Та й ця «романтика комунарів» здебільшого проглядається в «Спробі втечі» та «Важко бути богом», а в «Пікніку на узбіччі» та «За мільярд років до кінця світу» вже цілком аполітичні твори. В останньому 3 них радянська система вже продемонстрована без особливого пієтету - на подібні «фарби» вплинув і особистий досвід 
письменників (Бориса Стругацького допитували по «дисидентській лінії»).

Повість «Спроба втечі» написана в 1962 р. У тому самому році вона була надрукована у видавництві «Молода гвардія». Звичайно, що в повісті ми можемо спостерігати творчу манеру та проблематику «ранніх Стругацьких». Та частина 3 оптимістичних матеріалів уже знаходиться в незримому тяжінні до філософського осмислення приречення та складності, що пізніше набули вираження в творчості письменників. Але орієнтація на читача передусім охоплювала пригодницький спектр, головні герої були носіями «духу епохи» i їхня реакція на «зло» містила в собі природній стан «морального кодексу радянської людини». При цьому брати Стругацькі вміло виписали в творі чотири культурно-історичні парадигми, що «зіткнулися» на Саулії.

Перша парадигма була синтезована 3 сучасного письменникам уявлення про майбутнє, друга - це парадигма тоталітарної держави часів Другої світової війни, третя - аналог Середньовіччя. Четверта структура найзагадковіша - це концепція Мандрівників (рос. - Странников). Деякі критики закидали, що подібне нагромадження структур може призвести до плутанини і розмиття ідеї твору. Почасти молоді Стругацькі сміливо йшли на подібні експерименти - вони не боялися складнощів. У плутаних парадигмах вони намагалися вирішити свою глобальну проблему - втечі від фальші придуманих майбутніх «позитивів» без пояснення мотивації переродження людини в «досконалого комунара».

Спочатку письменникам було достатньо створити в перших творах блискучі прообрази «Світу Полудня» - перемога комунізму та «вирішення всіх проблем». Автори і читачі вдовольнялися «гарними картинками», цікавими пригодами в космічному антуражі тощо. Але «правда життя» вимагала відійти від фанерних бутафорських образів, оскільки залишалася проблема «бракуючої ланки» - як недосконалі люди перетворяться на досконалих? Чи взагалі це можливо? Звичайно, що «дешевий прийом» із часом уже не працював 
(мовляв, мине 50-100-500 років і ми станемо «краще»). Часом неможливо пояснити саме «якісні зміни», оскільки саме вони становлять собою «найбільшу проблему».

Та боротьба «за правду» в радянських умовах повинна була захована під пласти відволікаючих художніх нашарувань цензура пильно слідкувала за творчістю Стругацьких, як тільки вони почали відходити від шаблонних уявлень про «оптимістичну радянську дійсність» у майбутньому (та й паралелі з сучасними письменникам реаліями СРСР також «враховувалися»). Складність (а часто - неможливість) «пошуків правди» так влучно висловив Сергій Довлатов: «Як відомо, в наших газетах тільки друкарські помилки правдиві» [6, c. 205].

Головною «знахідкою» повісті «Спроба втечі» стала багатопланова картина передбачення парадигми людського існування. Багатоплановість повісті забезпечувала різні рівні розуміння - молодші школярі читали їі як суто пригодницьку, старші - як пригодницьку з елементами важливого «іспиту на людяність», який вони починали розуміти (оскільки вже більш чітко уявляли складність морального вибору). Більш вдумливі читачі могли «побачити» в повісті паралелі 3 радянською реальністю (Саул навіть мав тікати 3 «радянського концтабору», але автори зупинилися на «німецькому»). Ще перспективнішою виявилася «гілка Мандрівників» - потужної незрозумілої вищої сили, що своїми діями чи то спрямовує, чи то байдужа до долі людства (Всесвіту). Саме в цій парадигмі Стругацькі дали можливість «розігратися» фантазії читачів - ніяких «відповідей» вони не запропонували. Така «політика непояснення» значно збагатила твір - хоча в декого вона могла викликати роздратування, оскільки в радянські часи було прийняти всьому «надавати оцінку і пояснення». Та детермінізм, як відомо, тільки посилював (згідно «ефекту кобри») бажання людей побачити/почути «невідоме».

У межах нашої статті ми можемо виділити у «Спробі втечі» культурно-історичну парадигму «радянської лінії». Ця лінія представлена в творі «сучасним» (авторам) і «майбутнім» 
(малоймовірним внаслідок розвалу тридцять років тому СРСР, 2250 р.). Хоча повість починається «реаліями» XXIII ст., у ній легко вгадуються відгомони середини ХХ ст. - «класичний сусід» «дядя Саша» (такі образи сусідів були знайомі 3 повсякденного побуту, особливо за умов комунальної квартири чи дачного кооперативу). Яскравим взірцем такого «дяді» $\epsilon$ «дядя Юра» $з$ радянської телевізійної повісті «День за днем» (1971 р.). Автори серіалу дуже «вгадали» з подібними образами - їм прийшло біля 300000 листів! Безумовно, що Стругацькі також могли отримати «бонуси» від експлуатації «звичайної радянської людини». Та подібна парадигма тільки створювала емоційний «зацеп» тогочасного читача. Образ «сусіда» виписувався з тогочасних реалій - мало в кого був чи залишався батько (голодовки, війни, репресії тощо).

Стругацькі ніби прокидали місток між теперішнім i майбутнім: «- Все, - сказав Вадим. - Немає більше вашого скальпеля. Зате «колібрі» у вас тепер заряджений. Годин на тридцять безперервного ходу. Сусід пішов навколо гелікоптера, безцільно чіпаючи його за різні частини. Вадим засміявся i повернувся до столу. Він доїдав другий бутерброд і допивав другу склянку кислого молока, коли клацнув замок інформатора і тихий, спокійний голос сказав: - Викликів і відвідин не було. Антон, йдучи в місто, бажає доброго ранку і пропонує негайно після сніданку почати відмову від усього земного. В інститут надійшло дев'ять нових завдань...» [10, сс. 8-9]. Але подібні «картинки» виконували ще й функцію підсилення контрасту 3 «ворожим світом». Безконфліктний світ містив потенціал у будь-який момент перетворитися на жахливу пустелю моральну i фізичну. Зустріч із жорстокістю, трупами, вбивствами, експлуатацією тощо потребувала від людей «табірної кмітливості», яку мав Саул Рєпнін. Тільки така людина виявилася здатна реально протидіяти злу i «зло» розуміло тільки подібну «мову». Стругацькі могли спостерігати у своєму реальному житті таких людей - після смерті Сталіна мільйони повернулися «з таборів», із поселень. Ці люди мали 
вже іншу формацію мислення, вони нічого не боялися та сміливо могли відстоювати свою думку.

Саул Рєпнін почувався себе ніяково в «майбутньому». Він звик до «іншого життя». Почасти зрозуміти невідповідність «зеківського інтелігента» 3 сучасниками може допомогти творчість Юрія Домбровського - його особистий досвід бринить у кожному рядку. Освічені та високоінтелектуальні люди, потрапивши в реалії в'язниць і таборів, поверталися доволі своєрідними - вони поєднували «нові» жорстокі якості 3 залишками «колишнього» культурного нашарування. Все це підкріплялося силою незламного духу, відчайдушністю, недовірою та обачністю. Коротко стан Саула Рєпніна можна описати віршем Юрія Домбровського (особливо його останньою частиною, своєрідною алюзією на 66 сонет Шекспіра):

Меня убить хотели эти суки,

Но я принес с рабочего двора

Два новых навостренных топора.

По всем законам лагерной науки

Пришел, врубил и сел на дровосек;

Сижу, гляжу на них веселым волком:

«Ну что, прошу! Хоть прямо, хоть проселком...»

- Домбровский, - говорят, -

ты ж умный человек,

Ты здесь один, а нас тут... Посмотри же!

- Не слышу, - говорю, пожалуйста, поближе!

Не принимают, сволочи, игры.

Стоят поодаль, финками сверкая,

И знают: это смерть сидит в дверях сарая,

Высокая, безмолвная, худая,

Сидит и молча держит топоры!

Как вдруг отходит от толпы Чеграш,

Идет и колыхается от злобы:

- Так не отдашь топор мне?

- Не отдашь!

- Ну, сам возьму! 


$$
\begin{aligned}
& \text { - Возьми! } \\
& \text { - Возьму! } \\
& \text { - Попробуй! }
\end{aligned}
$$

Он в ноги мне кидается, и тут, Мгновенно перескакивая через, Я топором валю скуластый череп, И - поминайте, как его зовут!

Его столкнул, на дровосек сел снова: «Один дошел, теперь прошу второго!»

И вот таким я возвратился в мир, Который так причудливо раскрашен. Гляжу на вас, на тонких женщин ваших,

На гениев в трактире, на трактир,

На молчаливое седое зло,

На мелкое добро грошовой сути, На то, как пьют, как заседают, крутят, И думаю: как мне не повезло!

Відповідно, в самій назві твору «Спроба втечі», а особливо в його фіналі, подана основна концепція неможливості змінити парадигму існування, вийти за межі людської природи силами самої людини. Люди приносять всюди свої «проблеми», що тільки множаться «спробами втечі». Нескінченний потік машин «нуль-перекидки», що залишили Мандрівники, знаходиться «по той бік добра та зла». I ці механізми спричиняють страждання деяким, здивування іншим, і ніхто не може дати їм ради. Саул Рєпнін марно намагається зупинити цей потік - для нього це тільки емоційна розрядка, що не має жодного впливу на реальність.

Але «Спроба втечі» все ж тільки намічає проблеми зміни культурно-історичних парадигм. Це викликано тим, що в ній все ж сильніший «пригодницький дух».

Більш чітко протидію парадигм і їх взаємодії ми бачимо в повісті «Важко бути богом». Вона побачила світ у 1964 р. На відміну від попереднього твору, парадигми «Важко бути богом» перебувають у діалектичній єдності. Не випадковий фінал 
повісті - добро та зло дивовижно перепилося в особі Антона. Стругацьким було не важко вловити «подвійність» радянської культурно-історичної парадигми. Власне, вони були сучасниками багатьох подій, що накладали «свій відбиток» на «хомо совєтікус». Більш вільний у своїх судженнях Довлатов на еміграції вже міг вільно надрукувати художньо-публіцистичну характеристику знаних «комунарів»: «...Раз високий і огрядний Олексій Толстой ішов із видавничого коридору. Назустріч бігла моя тітка. Худенька і невисока, вона 3 розгону вдарилася Толстому головою в живіт. - Ого! - сказав Толстой, потираючи живіт. - А якби тут знаходилося око?! .. Тітка знала безліч смішних історій. Потім, самостійно, я дізнався, що Бориса Корнілова розстріляли. Що Зощенко прославив рабську табірну працю. Що Олексій Толстой був негідником і лицеміром. Що Ольга Форш запропонувала вести літочислення з моменту, коли народився якийсь Джугашвілі (Сталін). Що Леонов спекулював килимами в евакуації. Що Віра Інбер вимагала страти свого двоюрідного брата (Троцького). Що допитливий Павленко ходив дивитися, як допитують Мандельштама. Що Юрій Олеша зрадив свого друга Шостаковича. Що письменник Мірошниченко бив дружину велосипедним насосом ... I багато іншого. Тітка ж пам'ятала, в основному, смішні історії. Я іiі не звинувачую. Наша пам'ять вибіркова, як урна» [6, с. 194].

Саме проблему «прихованої сутності» ми можемо вважати ключовою для трактування неможливості автоматичного зміщення чи заміни парадигми. Не витримувала в першу чергу тонко організована психіка - вона ставала нездатна «перетравити» невідповідності між «бажаним i дійсним». У повісті «Важко бути богом» наводяться «приклади» того, що «комунари божеволіють»: «Десять років тому Стефан Орловський, він же дон Капада, командир роти арбалетників його імператорської величності, під час публічних тортурів вісімнадцяти Есторских відьом наказав своїм солдатам відкрити вогонь по катам, зарубав імперського суддю і двох судових приставів i був піднятий на списи палацовою охороною. Корчачись у передсмертній муці, він кричав: “Ви ж люди! Бийте 
ïx, бийте!” - але мало хто чув його за ревом натовпу: “Вогню! Ще вогню!” Приблизно в той же час в іншій півкулі Карл Розенблюм, один 3 найбільших знавців селянських воєн в Німеччині і Франції, він же торговець вовною Пані-Па, підняв повстання мурісськіх селян, штурмом взяв два міста і був убитий стрілою в потилицю, намагаючись припинити грабежі. ..А незадовго до прибуття Румати чудово законспірований одинконфідент кайсанского тирана (Джеремі Тафнат, фахівець із історії земельних реформ) раптом ні 3 того ні з сього справив палацовий переворот, узурпував владу, протягом двох місяців намагався впровадити Золотий Вік, вперто не відповідаючи на люті запити сусідів і Землі, заслужив славу божевільного, щасливо уникнув восьми замахів, був, нарешті, викрадений аварійною командою співробітників Інституту і на підводному човні переправлений на острівну базу біля Південного полюсу...» [10, сс. 133-134].

Подібні «зриви» почасти запрограмували й «збій програми» самого Антона - «парадигма зла» перемогла в його душі. Стругацькі зуміли органічно виписати сутність проблеми - відсутність реальних важелів трансформації особистості на позитивних засадах. Певна надія покладалася на радянську соціальну інженерію - на освіту, армію, «колектив» тощо. Вважалося, що десятиліття «радянської школи» здатні будуть із часом сформувати «правильну людину». Але вже в роки написання повісті подібні надії розвіювалися. При віддаленні від Другої світової війни ступінь оптимізму зменшувався, вже через декілька років вийде «Обмін» Юрія Трифонова, де буде чітко продемонстровано значну перевагу пройдисвітів у радянських реаліях. Чому ж перемога у Другій світовій війні додавала спочатку так багато оптимізму? Після таких випробувань люди раділи всім ознакам «мирного життя», а також вірили, що, переживши таку колосальну кризу, людство вже не повторить подібних помилок і буде тільки розвивати добро.

Протягом 1971 р. брати Стругацькі створили одну зі своїх найвідоміших повістей - «Пікнік на узбіччі». Частково це 
ще твір із структурними елементами «класової системи». Водорозділ між «нашими» і «чужими» закладений у тканину твору, але «наші» лише присутні у вигляді знеособлених штампів (позитивний Кирило Панов повинен за задумом авторів викликати симпатію, але він все ж епізодичний, плоско виписаний персонаж). А ось «чужі» вже містять у собі всі психологічні ознаки дискурсу переосмислення усталеної життєвої парадигми. В більш широкому ракурсі «Пікнік на узбіччі» переходить у загальнолюдську дискусію про призначення людини, про складність віднайдення сенсу життя. В повісті «радянська парадигма» вже виглядає доволі «штучним шаблоном», що не має жодного живого зв'язку з реальним життям. На початку сімдесятих років дискусія між «Заходом i Сходом» уже загубила свою гостроту. Процес «ідеологічного розкладання» радянського суспільства набув незворотніх темпів.

Ці процеси відбувалися поступово, Стругацькі їх просто опосередковано відтворювали в своїх творах. Динаміка розпаду i розладу набула в 70-их pp. XX ст. загрозливих для СРСР величин (хоча про «фінал імперії зла» в найближчому майбутньому не мріяли навіть іiі щирі вороги). Саме прибічники радянського режиму вже бачили зміну парадигм. Зокрема, наприкінці 70-х pp. XX ст. це стало причиною самогубства одного зі «стовпів» радянської філософії, «останнього прибічника марксизму, що в це вірив щиро» («Ільєнков був останнім, хто всерйоз і 3 талантом намагався вдихнути у філософію марксизму нове життя, підвищити його конкурентоспроможність у боротьбі ідей. Але й він, як можна тепер констатувати, зазнав поразки. Наприкінці життя його вплив на молодь почав падати, число учнів скорочуватися i, як мені здається, він усе гостріше відчував свою філософську самотність. Це, можливо, і стало головною причиною його особистої трагедії» [12, с. 277]) - Ільєнкова Евальда Васильовича: «У передостанній понеділок свого життя на цьому семінарі виступив 3 доповіддю Евальд Ільєнков. Зал, як зазвичай, був повний ... Скажу лише, що опонент Евальда був 
свого часу його відданим другом i, як говорили мені старі співробітники Інституту філософії, ходив за ним як прив'язаний... Його неординарні і сміливі ідеї трощили у філософії і психології панівний у їх офіційно схвалених підставах вульгарний матеріалізм. Правда, з виходом в широкі простори напівмістичних одкровень ... В азарті полум'яної промови своєї він вигукнув: «Та я за один абзац Бердяєва віддам весь ваш марксізьм-ленінізьм!». Зал відповів йому зливою оплесків. - Пізно! Безнадійно пізно! Ви ж чули, як вони аплодували цьому плутанику?! Додому до себе, незважаючи на давню домовленість i начебто необхідність продовжити розмову, він нас не пустив, відговорившись розладом і втомою» [12, сс. 72-73].

Бачимо, що люди вже не так боялися висловлювати свої думки, тяжіли до оновлення структури та наповнення суспільного життя в СРСР. Але визнати ці зміни «офіційно» заважала та саме ідеологічна зацикленість на «непорушності». При цьому замовлення на «цькування капіталізму» набуло в «Пікніку на узбіччі» не просто соціального звучання - брати Стругацькі бачили, що він дійсно має безліч внутрішніх проблем. Без принципового оновлення людської природи неможливе автоматичне засвоєння нових життєвих реалій зруйнований соціалізм може замінити капіталізм, але люди залишаються такими саме людьми 3 тяжінням до різних полюсів добра та зла. Це продукує химери і часто просто «утилізує значну масу населення». В «Пікніку на узбіччі» показана «утилізація» активної молоді, що в гонитві за вдачею знаходить лише смерть і каліцтво. Вони зосередили свою увагу на подоланні «звірячої природи» людини, довели важливість правильного «морального вибору».

«Доба див» у творчості Стругацьких змінилася «добою правильного вибору». Дива вже перестали бути магнітом уваги - мертві оживали та артефакти змінювали закони фізики. Але ці «дива» ніяк не впливали на моральний стан людей - вони залишалися такими саме «загубленими». Більш того - мутації дітей сталкерів стали прямим наслідком «Зони», що теж $\epsilon$ 
своєрідним «дивом». Але це «диво» завдавало чималої деструкції людській психіці та руйнувало і так хиткі сподівання на більш-менш надійний «родинний прихисток».

Несподіваний для радянської літератури і фінал повісті звернення до Бога, озвучування загального щастя. Ця «перемога» моралі була досягнута шляхом катарсису. Стругацькі ніби «нащупали шлях» оновлення - через страждання людина мала очиститися та «все зайве» відпадало. Ніби смерть, біль і страждання залишали в людині справжнє зерно, а гонитва за матеріальними благами та цинізм лише затримували «оновлення». Редріку Шухарту знадобилися роки для досягнення стану справді «хорошої людини», яка йде на шляху до очищення. Та Стругацькі реалісти - подібний шлях підходить лише для тих, хто ще зберіг у собі частину «добра», бо вони контрастують із «повністю гнилими людьми». «Гнилі» персонажі вважаються безперспективними в будь-яких варіаціях. Навіть смерть їх дітей розглядається елементом справедливості за загублені ними життя. Подібні складні мотиваційні конструкції було можливо описати лише у «псевдозахідній» реальності, де штучно «очищений» радянський рівень свідомості був інтегрований у рамках «міжнародного проекту».

У 1976 р. у журналі «Знание-сила» була надрукована науково-фантастична повість «За мільярд років до кінця світу». В цьому творі відкривається нова культурно-історична парадигма, що звичайно містить у собі унікальний код життєвого досвіду письменників у царині осягнення «долі людини і долі світу». Дія повісті відбувається в добу глибокого застою в Ленінграді. Відповідно до теми нашої публікації, радянська культурно-історична парадигма доповнена в повісті «невидимою силою», що тяжіє над дослідниками і змушує їх припинити ті чи інші напрямки своєї діяльності. Внутрішнє напруження твору досягається динамікою морального вибору, намаганням зберегти особистість в екстремальних випробуваннях. Стресотійкі «радянські вчені» по-різному відреагували на «попередження», губилися в багатоманітній 
природі загрози, що не вписувалася в «класичну» усталену модель буття.

Парадигма «застою» була доволі точно зображена у повісті. Звичайно письменники уникали прямих висловів щодо «партійної еліти». Такі «вольності» могли собі дозволити тільки ті, хто перебував за межами СРСР. Сергій Довлатов легко та іронічно критикував партійну верхівку (при цьому обігруючи це в специфічній творчій манері) - епізод про собаку, що отримала за свій вчинок «надзвичайний» подарунок: «Вдень їй принесли 3 буфету ЦК чотириста грамів шийної вирізки. Випадок унікальний. Може бути, вперше партійні пільги торкнулися гідного об'єкта...» [6, с.243]. Для Стругацьких «продовольча тема» також слугувала маркером «становища в радянському суспільстві». Їжа була своєрідним фетишем, що демонстрував «вміння жити». Звичайні люди мали обмежені можливості «вдовольнити свої гастрономічні потреби», а верхівка та їхня «свита» розкошувала зі «спецрозподільників».

Відповідно, у повісті «За мільярд років до кінця світу» письменники вміло продемонстрували цей перекіс радянської системи. Коробка з їжею зі стола замовлень у повісті відіграє роль «емоційної бомби». Сьогодні ми це можемо розуміти тільки з багажем знань про умови життя в тогочасному СРСР. Навіть місце дії - Ленінград - не зменшує, а ще й збільшує відчуття невпорядкованості радянського побуту. «Північна столиця» аж ніяк не має захисту від дефіциту. Парадигма радянського «виживання» змістилася в ті часи 3 фізичного виживання в бік урізноманітнення їжі. Але механізми цього урізноманітнення були фантастичні. Саме ці концепти почали закладати в застійному СРСР підвалини майбутньої зміни еліт інтелігенція вже демонструвала чіткі ознаки «вимирання». Це дуже точно підмітив Юрій Трифонов у циклі своїх «московських повістей». Поза дефіцитом лишалися герої повісті «За мільярд років до кінця світу» Філіп Вечеровський (мав доступ до закордонних товарів і поїздок) та Арнольд Снєговий (вчений у званні полковника, отримував забезпечення через «спецрозподілення»). Та Вечеровський виглядає «останнім із 
могікан», його доля в кінці повісті непередбачувана. У Трифонова «лук'янови» витісняють «дмитрієвих», ловкачі перемагають книголюбів і романтиків. При цьому Ленінград додає ще одну площину осмислення етапів розвитку радянського суспільства. Ленінградська блокада була одним із чинників, що вплинула на свідомість Стругацьких, сформувала їх ставлення до багатьох сфер життя. У спогадах Борис та Аркадій Стругацькі згадували, як випробування голодом загартовувало їх родину, надало своєрідне ставлення до «подій реальності».

«Зустріч 3 владою» у Стругацьких обігрується 3 не меншим запалом - «владою» виступає екзотичний слідчий. Він краде у вченого пляшку коньяку, що ставить Малявіна в тупик. Астрофізик не може «розкрити код» каральної системи, не бачить ніяких реальних важелів взаємодії з нею. Будья-який крок видавався абсурдним за своєю формою та змістом. Зосередитись «радянській людині» заважає й печерний страх перед представниками силових структур, думка про те, що будьяка «людина у формі» може назавжди змінити твоє життя (здебільшого не в кращий бік). Подібні роздуми були і в Сергія Довлатова:

«Мені згадується така історія. Йшли ми 3 приятелем 3 лазні. зупиняє нас міліціонер. Ми насторожилися, запитуємо:

- У чому справа?

А він каже:

- Ви не пам'ятаєте, коли були видані «Чотки» Ахматової?

- У тисяча дев'ятсот чотирнадцятому році. Видавництво «Гіперборей», Санкт-Петербург.

- Дякую. Можете йти.

- Куди? - запитуємо.

- Куди хочете, - відповідає. - Ви вільні...

Мене вразила тоді суміш буденності і божевілля. I в цей раз приблизно таке ж відчуття». [6, с.248]

Подібні письменницькі пошуки привели Довлатова до цікавої думки: «То ж, єдина зброя в боротьбі проти радянської держави - абсурд...» [6, с.259]. Брати Стругацькі не виступали 
«борцями 3 режимом», вони просто намагалися чесно попередити людей про вади суспільства, намагалися покращити стан «своєї батьківщини».

А проблеми в застійному СРСР продовжували накопичуватися - лубок не міг приховати внутрішню деструкцію радянської держави: «Дитяча смертність почала зростати в 1971 р., а тривалість життя чоловіків почала падати в 1965 р. Цього року тривалість життя чоловіків у СРСР відставала від американських показників лише на 2,5 роки, а тривалість життя радянських жінок практично зрівнялася 3 американською. Але вже в 1980 р. відставання від США за тривалістю життя досягло 8,5 років у чоловіків і 4,3 років у жінок. Це супроводжувалося i збільшенням споживання алкоголю. У 1960-х споживання алкоголю майже подвоїлася - 3 4,6 до 8,3 л на душу населення на рік. До кінця 1970-х цей показник перевищив 10 л...» [5].

Стругацькі спробували «вгадати» структуру історикокультурної парадигми СРСР. Оптимізм їх перших творів змінився розумінням «кому проблем», що так i не знайшли вирішення. Частковим «вирішенням» стало припинення існування СРСР. Та «довгі тіні минулого» й досі тісно переплетені 3 нашим сьогоденням i сягають зримого майбутнього.

Висновки. Історико-культурний контекст дозволяє побачити справжню глибину проблематику творчого доробку братів Стругацьких. Безумовно, що не всі ідеї можуть бути витлумачені дослідниками i читачами у тому вигляді, що закладені авторами. Та Стругацькі здійснили «заділ на майбутнє» - вони зуміли закласти у тканину своїх творів надзвичайний потенціал інтелектуального багатства, що зумів здолати грубе соціологізаторство та й досі привертає до себе увагу. Саме цей творчий потенціал дозволяе сьогодні вповні проаналізувати різноманітні комбінації інтеграції, асиміляції, боротьби, інкорпорації різних культурно-історичних парадигм мислення. Подібне «моделювання» існувало не тільки для «розважальної складової», але й містило в собі інтелектуально- 
філософську позицію Аркадія та Бориса Стругацьких, дозволяло їм донести до вдумливого читача свої мрії, роздуми та острахи перед «битвами майбутнього». Чи зможе добро «виграти»? Який інструментарій наявний у людства для здолання негативного досвіду та побудови «світлого майбутнього»? Наукова фантастика ніби дозволяла любі «фокуси», та письменники здебільшого відкинули грубу механіку фальсифікації та підміни морально-психологічних законів. Вони продемонстрували конфлікт парадигм мислення в різних «світах» і часто залишали відкритим питання спроможності людини віднайти дієві чинники позитивного осмислення дійсності, часто залишали головних героїв у розпачі. Саме ці якості дозволили залишити живу природи творчості Стругацьких. Ми певні, що в майбутньому їх доробок принесе ще більше знахідок.

\section{Список використаної літератури:}

1. Антонец В.А. Культурный смысл противостояния человека и тоталитарного общества. Ярославский педагогический вестник. 2012. №3 Сс. 243-245.

2. Братусь І.В. Протидія системи й антисистеми в повісті братів Стругацьких «Равлик на схилі». Українські культурологічні студії. 2021. №8. Сс. 5-9.

3. Братусь I.B., Свердлик 3.M., Гунька А.М. Свобода та несвобода в повісті братів Стругацьких «За мільярд років до кінця світу». Молодий вчений. 2021 № 93. Сс. 226-230.

4. Бурцев Г.В., Казаков А.А. Интертекстуальный контекст рецепции Р. Д. Брэдбери в творчестве братьев А.Н. и Б.Н. Стругацких (литературная традиция Ф.М. Достоевского и Ф. Кафки). Наука о человеке: гуманитарные исследования. 2020. № 14. С. 19-29.

5. Гуриев С., Цывинский О. Ностальгировать по СССР не стоит.

URL:https:/www.vedomosti.ru/opinion/articles/2009/10/13/nostalgir ovat-po-sssr-ne-stoit 
6. Довлатов С. Собрание прозы в четырех томах. Т. 2. Сергей Довлатов. Санкт-Петербург: Азбука, Азбука-Аттикус. 2017. $416 \mathrm{c}$.

7. Королькова П.В. К вопросу о разграничении фэнтези и литературной волшебной сказки. Вестник Московского университета. Серия 9. Филология. 2011.№ 1. Сс. 59-66.

8. Микешин М.И. Социальная метафизика братьев Стругацких. Вестник ЛГУ им. А.С. Пушкина. 2015. №4. Сс. 243253.

9. Обвинцева О.В., Обвинцева Т.О. Репрезентация концепта наука в повести Аркадия и Бориса Стругацких «Пикник на обочине». Вестник Томского государственного педагогического университета. 2021. № 4. Сc. 91-99.

10. Стругацкий А., Стругацкий Б. Попытка к бегству. Трудно быть богом. Хищные вещи века. Москва: Текст, 1992. $415 \mathrm{c}$.

11. Тельпов Р.Е. Художественные функции имен собственных в повести братьев Стругацких «Улитка на склоне». Мир науки, культуры, образования. 2008. №1. Сс. 64-66.

12. Эвальд Васильевич Ильенков в воспоминаниях. Москва, РГГУ, 2004. 309 с. 
Иван Викторович БРАТУСЬ,

кандидат филологических наук, доцент, Киевский университет имени Бориса Гринченко,

Киев, Украина, e-mail: i.bbratus@kmaecm.edu.ua, ORCID: 0000-0002-8747-2611

\title{
ПОПЫТКА ОСМЫСЛЕНИЯ КУЛЬТУРНО- ИСТОРИЧЕСКИХ ПАРАДИГМ В ТВОРЧЕСТВЕ БРАТЬЕВ СТРУГАЦКИХ («ПОПЫТКА К БЕГСТВУ», «ТРУДНО БЫТЬ БОГОМ», «ПИКНИК НА ОБОЧИНЕ», «ЗА МИЛЛИАРД ЛЕТ ДО КОНЦА СВЕТА»)
}

\begin{abstract}
Аннотация. В статье мы осуществили попытку продемонстрировать осмысление изменения культурноисторических парадигм в творчестве братьев Стругацких. Произведен анализ основных произведений писателей: «Попытка к бегству», «Трудно быть богом», «Пикник на обочине», «За миллиард лет до конца света» с точки зрения переосмысления парадигм мышления. Доказывается, что каждая новая эпоха вызывает новые факторы восприятия действительности. В статье делается акцент на способность братьев Стругацких предвидеть будущие изменения в обществе. Кроме этого, должное место в исследовании отводится механизмам мотивационного поиска, раскрывавшимся в моделях вероятного развития человечества. Анализируются элементы советской действительности, которые добавляют параллелизма произведениям писателей. Рассмотрены факторы закрепления различных элементов мышления в четкую структуру общественной жизни. Особое внимание мы уделяем «правде жизни», которая могла быть продемонстрирована братьями Стругацкими лишь частично (цензурные ограничения). Нами введены в текст статьи отрывки из автобиографических произведений Сергея Довлатова - $\mathrm{c}$ помощью этих цитат создается более полная картина советской действительности. Эта реальность позволяет строить условные
\end{abstract}


конструкты будущего, анализировать настоящее и осуществлять историческую ретроспекцию прошлого. Фокус исследования позволяет нам отследить оттенки зарождения свободы в эпоху позднего «застоя», что было вызвано углублением системного кризиса в СССР. Братья Стругацкие плодотворно работали в области выяснения «внутренней мотивации советского человека». Эти исследования находили живой отклик в советском обществе -творчество писателей носило полудемократический формат, что в условиях авторитаризма очень ценилось. Именно благодаря такому «статусу» писателям удалось оставить произведения приемлемыми для официальной печати в СССР и продемонстрировать в них проблемы общества. В своей творческой эволюции братья Стругацкие отошли от вульгарного социологизаторства первых своих произведений и совершили настоящий психологических прорыв в осмыслении человеческого бытия, который отчасти не теряет актуальности и в описываемом ими XXI веке. При этом действительность у Стругацких часто балансирует на грани абсурда, что позволяло им более глубоко отследить механизмы «судьбы».

Ключевые слова: Борис Стругацкий, Аркадий Стругацкий, фантастика, парадигма мышления, советская литература, будущее 
Ivan V. BRATUS,

PhD in Philology, Associate Professor,

Borys Grinchenko Kyiv University,

Kyiv, Ukraine,

e-mail: i.bratus@kmaecm.edu.ua,

ORCID: 0000-0002-8747-2611

\section{ATTEMPT OF CONSIDERIG OF CULTURAL AND HISTORICAL PARADIGMS IN THE WORKS OF THE STRUGATSKY BROTHERS («ESCAPE ATTEMPT» , «HARD \\ TO BE A GOD», «ROADSIDE PICNIC», «ONE BILLION YEARS TO THE END OF THE WORLD»)}

Abstract. In the article, we made an attempt to demonstrate the understanding of the change in cultural and historical paradigms in the work of the Strugatsky brothers. The analysis of the main works of the writers: "Attempt to escape", "It is difficult to be a god", "Roadside picnic", "A billion years before the end of the world" from the point of view of rethinking the paradigms of thinking. It is proved that each new era brings about new factors of perception of reality. The article focuses on the ability of the Strugatsky brothers to foresee future changes in society. In addition, a due place in the study is given to the mechanisms of motivational search, revealed in the models of the probable development of mankind. The elements of Soviet reality are analyzed, which add parallelism to the works of writers. The factors of consolidation of various elements of thinking in a clear structure of social life are considered. We pay special attention to the "truth of life", which could only be partially demonstrated by the Strugatsky brothers (censorship restrictions). We have introduced excerpts from the autobiographical works of Sergei Dovlatov into the text of the article - with the help of these quotes, a more complete picture of Soviet reality is created. This reality allows us to build conditional constructs of the future, analyze the present and carry out a historical retrospection of the past. The focus of the research allows us to trace the shades of the emergence of freedom in the era of late 
"stagnation", which was caused by the deepening of the systemic crisis in the USSR. The Strugatsky brothers worked fruitfully in the field of clarifying the "internal motivation of the Soviet man". These studies found a lively response in Soviet society - the creativity of the writers was of a semi-democratic format, which was highly valued under the conditions of authoritarianism. It was thanks to this "status" that the writers managed to keep their works acceptable for the official press in the USSR and demonstrate in them the problems of society. In their creative evolution, the Strugatsky brothers moved away from the vulgar sociologization of their first works and made a real psychological breakthrough in understanding human existence, which partly does not lose its relevance in the 21 st century they are describing. At the same time, the Strugatskys' reality often balances on the brink of absurdity, which allowed them to trace more deeply the mechanisms of "fate".

Key words: Boris Strugatsky, Arkady Strugatsky, fiction, paradigm of thinking, Soviet literature, the future

\section{References:}

1. Antonets, V.A. (2012). Kul'turnyy smysl protyvostoyanyya cheloveka y totalytarnoho obshchestva [The cultural meaning of the confrontation between man and totalitarian society]. Yaroslavskyy pedahohycheskyy vestnyk, 1, 3, 243-245 [in Russian]

2. Bratus, I.V. (2021). Protydiya systemy y antysystemy v povisti brativ Struhats'kykh "Ravlyk na skhyli" [Counteraction of the system of antisystems in the life of the Strugatsky brothers "Sail on the slope"]. Ukrayinski kulturologichni studiyi, 8, 5-9 [in Ukrainian]

3. Bratus I.V.\& Sverdlik Z.M. \& Gun'ka A.M. (2021). Svoboda ta nesvoboda v povisti brativ Struhats'kykh "Za mil'yard rokiv do kintsya svitu" [Freedom and lack of freedom in the life of the Strugatsky brothers "For the billions of years until the end of the day"]. Molodiy Vchenii, 5, 226-230 [in Ukrainian]

4. Burtsev G. \& Kazakov, A. (2020). Yntertekstual'nyy kontekst retseptsyy R. D. Brédbery $v$ tvorchestve brat'ev A.N. i B.N. Struhatskykh (lyteraturnaya tradytsyya F.M. Dostoevskoho i 
F. Kafky) [Intertextual context of RD Bradbury's reception in the works of brothers A.N. and B.N. Strugatsky (literary tradition of F.M. Dostoevsky and F. Kafka)]. Nauka o cheloveke: humanytarnye yssledovanyya, 1, 19-29 [in Russian]

5. Guriev, S. \& Tsyvinsky, O. Nostal'hyrovat' po SSSR ne stoyt [Nostalgic for the USSR is not worth]. Available at: https://www.vedomosti.ru/opinion/articles/2009/10/13/nostalgirovatpo-sssr-ne-stoit [in Russian]

6. Dovlatov, S. (2017). Sobraniye prozy v chetyrekh tomakh. T. 2. Sergey Dovlatov [Collected prose in four volumes. V. 2, Sergey Dovlatov]. Sainct-Petersburg: Azbuka, Azbuka-Attikus [in Russian]

7. Korolkova, P.V. (2011). K voprosu o raz hranychenyy féntezy y lyteraturnoy volshebnoy skazky [To the question of the delimitation of fantasy and literary fairy tale]. Vestnyk Moskovskoho unyversyteta. Seryya 9. Fylolohyya, 1, 59-66 [in Russian].

8. Mikeshin, M.I. (2015). Sotsyal'naya metafyzyka brat'ev Struhatskykh [Social metaphysics of the Strugatsky brothers]. Vestnyk LHU ym. A.S. Pushkyna, 243-253 [in Russian]

9. Obvintseva, O.V. \& Obvintseva, T.O. (2021). Reprezentatsyya kontsepta nauka v povesty Arkadyya y Borysa Struhatskykh "Pyknyk na obochyne". [Representation of the concept of science in the story of Arkady and Boris Strugatsky "Roadside Picnic"]. Vestnyk Tomskoho hosudarstvennoho pedahohycheskoho unyversyteta, 4, 91-99 [in Russian]

10. Strugatsky, A. \& Strugatsky, B. (1992). Popytka k behstvu. Trudno byt' bohom. Khyshchnye veshchy veka [Attempt to escape. It's hard to be a god. Predatory things of the century] [in Russian] 11. Telpov, R.E. (2008). Khudozhestvennye funktsyy ymen sobstvennykh v povesty brat'ev Struhatskykh "Ulytka na sklone". [Artistic functions of proper names in the story of the Strugatsky brothers "The snail on the slope"]. Myr nauky, kul'tury, obrazovanyya, 1, 64-66 [in Russian

12. Éval'd Vasyl'evych Yl'enkov v vospomynanyyakh (2004) [Evald Vasilievich Ilyenkov in memoirs] [in Russian] 